\title{
Komparasi Metode Simple Additive Weighting dan Profile Matching pada Pemilihan Mitra Jasa Pengiriman Barang
}

\author{
Tri Yani Akhirina ${ }^{\# 1}$ \\ ${ }^{\#}$ Teknik Informatika Fakultas Teknik dan MIPA Universitas Indraprasta PGRI \\ Jalan Nangka no. 58 Tanjung Barat Jagakarsa Jakarta Selatan \\ Telp : (021)7885283, Fax : (021)8718718 \\ ${ }^{1}$ azizahputriku@gmail.com
}

\begin{abstract}
Abstrak - Toko Bedjo Auto Accesoris merupakan badan usaha yang berkembang dibidang retail accesoris mobil baik secara konvensional maupun online. Pengiriman barang adalah rutinitas yang dilakukan dalam bisnis ini. Sehingga pemilihan mitrajasa pengiriman barang selalu dilakukan pihak manajemen secara berkelanjutan, agar kepuasan pelanggan terjaga. Penelitian sebelumnya telah di implementasikan metode SAW untuk mendukung keputusan pemilihan mitra jasa transportasi ini. Dalam pengembangannya penulis melakukan komparasi dengan metode Profile Matching dalam menentukan mitra jasa pengiriman barang, menggunakan data dan penilaian yang sama. Hasil komparasi dari kedua metode diatas adalah menghasilkan alternatif terpilih yang sama, sehingga kedua metode tersebut dapat diterapkan untuk membantu pengambilan keputusan pihak manajemen.
\end{abstract}

Kata kunci- Sistem Pendukung Keputusan, Metode Simple Additive Weighting, Metode Profile Matching, Komparasi, Mitra Jasa Pengiriman Barang

\section{Pendahuluan}

Toko Bedjo Auto Accesoris (BAA) adalah toko yang sedang berkembang dibidang retail accesoris mobil. Perusahaan ini menjual berbagai accesoris mobil baik secara grosir maupun eceran. Selain menjual secara konvensional di tiga cabang di daerah jabodetabek, toko ini juga menjajakan produk-produknya di dunia maya. Pangsa pasar toko BAA tidak hanya di Jakarta akan tetapi sampai ke daerah seperti kalimantan, papua dan sumatera. Pelayanan prima dan kepuasan pelanggan adalah hal yang sangat diutamakan oleh pihak toko BAA.

Salah satu kendala yang dihadapi adalah jenis-jenis dari barang dagangan toko ini memiliki berbagai karakteristik seperti, mudah pecah, dimensi dari kecil sampai besar dan lain sebagainya. Kendala lain adalah toko BAA tidak memiliki kurir internal untuk mengantarkan barang pesanan ke pelanggan secara langsung. Sehingga untuk pengiriman barang selalu mengandalkan jasa pengiriman barang..

Pada penelitian ini penulis memilih dua metode yaitu metode Simple Additive Weighting dan Profil Matching untuk diimplementasikan dalam pemilihan mitra jasa pengiriman barang. Metode Simple Additive Weighting (SAW) telah diterapkan dalam penelitian sebelumnya dengan judul "Sistem Pendukung Keputusan dalam Pemilihan Mitra Jasa
Pengiriman Barang Menggunakan Metode Simple AdditiveWeighting (SAW)"[1]. Metode SAW membutuhkan proses normalisasi matriks keputusan (X) berdasarkan persamaanyang disesuaikan dengan jenis atribut (atribut keuntungan ataupun atribut biaya) sehingga diperoleh matriks ternormalisasi R. Hasil akhir diperoleh dariproses perankingan yaitu penjumlahan dari perkalian matriks ternormalisasi $\mathrm{R}$ dengan vektor bobot sehingga diperoleh nilai terbesar yang dipilih sebagai alternatif terbaik sebagai solusi. Metode ini merupakan salah satu metode MADM yang mana merupakan suatu metode yang digunakan untuk mencari alternatif optimal dari sejumlah alternatif dengankriteria tertentu.

Untuk mendapatkan hasil yang maksimal dalam pemilihan atlternatif, peneliti mengkomparasi data yang sama dengan metode Profile Matching. Metode Profile Matching merupakan proses membandingkan antara nilai data aktual dari suatu profil yang akan dinilai dengan nilai profil yang diharapkan, sehingga dapat diketahui perbedaan kompetensinya (disebut juga gap), semakin kecil gap yang dihasilkan maka bobot nilainya semakin besar.

Penelitian sejenis yang membahas dari sisi Sistem Pendukung Keputusan adalah Perbandingan Profile Matching dan Simple Additive Weighting pada penentuan Jurusan Siswa Kelas X SMA N 2 Ngaglik[2]. Pada penelitian ini kedua metode diterapkan dengan tiga kriteria, yaitu bakat, raport dan minat. Dari ketiga kriteria tersebut dilakukan perhitungan menggunakan kedua metode dan hasil yang diperoleh adalah kedua metode menghasilkan alternatif yang sama yaitu jurusan yang tepat bagi siswa.

Penelitian ini memiliki relevansi dengan penelitian sebelumnya yaitu menerapkan metode Simple Additive Weighting dan Profile Matching. Dimana untuk memperoleh hasil digunakan data alternatif dan kriteria yang sama. Dalam penelitian ini dilakukan komparasi antara kedua metode tersebut, yang bertujuan membantu pengambilan keputusan terbaik dalam pemilihan mitra jasa pengiriman barang yang sesuai dengan kebutuhan pihak manajemen, agar kepuasan konsumen dapat terjaga.

Kedua metode ini dipilih oleh penulis karena pada metode SAW atribut terbaik bisa menjadi solusi alternatif terbaik sedangkan pada metode Profile matching, atribut yang mendekati ideal yang akan menjadi solusi alternatif terbaik. 
Perbandingan dua metode ini bertujuan untukmengetahui tingkat keberhasilan penerapan metodepada penentuan mitra jasa pengiriman barang dengan menggunakan datadan kriteria yang sama.

\section{LANDASAN TEORI}

\section{A. Decision Suport System (DSS)}

Sistem pendukung keputusan/Decision Support System (DSS) merupakan system informasi interakif yang menyediakan informasi, pemodelan, dan pemanipulasian data [3]. Sistem ini digunakan untuk membantu pengambilan keputusan dalam situasi yang semi terstruktur dan situasi yang tidak terstruktur, di mana tidak seorang pun tahu secara pasti bagaimana keputusan seharusnnya dibuat [4]. Sistem pendukung keputusan merupakan sebuah sistem yang menyediakan kemampuan untuk penyelesaian masalah dan komunikasi untuk permasalahan yang bersifat semi-terstruktur [5].

Beberapa keuntungan penggunaan SPK antara lain adalah sebagai berikut: [6]

1) Mampu mendukung pencarian solusi dari berbagai permasalahan yang kompleks.

2) Dapat merespon dengan cepat pada situasi yang tidak diharapkan dalam konsisi yang berubah-ubah.

3) Mampu untuk menerapkan berbagai strategi yang berbeda pada konfigurasi berbeda secara cepat dan tepat.

4) Pandangan dan pembelajaranbaru.

5) Sebagai fasilitator dalam komunikasi.

6) Meningkatkan control manajemen dan kinerja.

7) Menghemat biayadan sumber daya manusia(SDM).

8) Menghemat waktu karena keputusan dapat diambil dengan cepat.

9) Meningkatkan efektivitas manajerial, menjadikan manajer dapat bekerja lebih singkat dan dengan sedikit usaha.

10) Meningkatkan produktivitas analisis.

Karakteristik dan kapabilitas kunci dari DSS ditunjukkan pada gambar 1. [7]

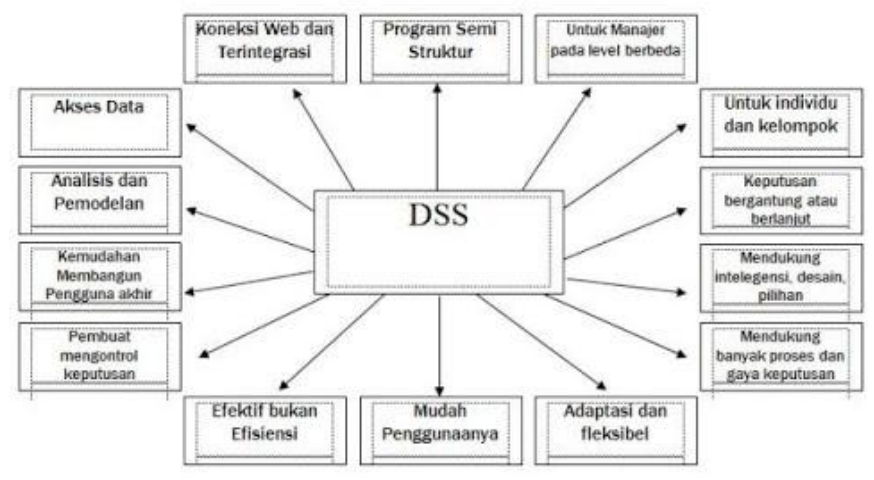

Gambar 1. Karakteristik dan Kapabilitas Kunci DSS

\section{B. Metode Simple Additive Weighting}

Metode Simple Additive Weighting (SAW) sering juga dikenal istilah metode penjumlahan terbobot. Konsep dasar metode SAW adalah mencaripenjumlahan terbobot dari rating kinerja pada setiap alternatif pada semua atribut [8]. Metode SAW membutuhkan proses normalisasi matriks keputusan (X) ke suatu skala yang dapat diperbandingkan dengan semua rating alternatif yang ada. Metode ini merupakan metode yang paling terkenal dan paling banyak digunakan dalam menghadapi situasi Multiple Attribute Decision Making (MADM)[9].

MADM itu sendiri merupakan suatu metode yang digunakan untuk mencari alternatif optimal dari sejumlah alternatif dengan kriteria tertentu. Metode SAW ini mengharuskan pembuat keputusan menentukan bobot bagi setiap atribut. Skortotal untuk alternatif diperoleh dengan menjumlahkan seluruh hasil perkalian antara rating (yang dapat dibandingkan lintas atribut) dan bobot tiap atribut.

Rating tiap atribut haruslah bebas dimensi dalam arti telah melewati proses normalisasi matriks sebelumnya.

Langkah Penyelesaian SAW sebagai berikut :

1) Menentukan kriteria-kriteria yang akan dijadikan acuan dalam pengambilan keputusan, yaitu $\mathrm{Ci}$.

2) Menentukan rating kecocokan setiap alternatif pada setiap kriteria.

3) Membuat matriks keputusan berdasarkan kriteria(Ci), kemudian melakukan normalisasi matriks berdasarkan persamaan yang disesuaikan dengan jenis atribut (atribut keuntungan ataupun atribut biaya) sehingga diperoleh matriks ternormalisasi R.

4) Hasil akhir diperoleh dari proses perankingan yaitu penjumlahan dari perkalian matriks ternormalisasi $R$ dengan vektor bobot sehingga diperoleh nilai terbesar yang dipilih sebagai alternatif terbaik (Ai)sebagai solusi.

Formula untuk melakukan normalisasi tersebut adalah :

$$
r_{i j}=\left\{\begin{array}{c}
\frac{X_{i j}}{\operatorname{Max} X_{i j}} \mathrm{Jika} \mathrm{j} \text { adalah atribut keuntungan } \\
(\text { benefit }) \\
\frac{\operatorname{Min} X_{i j}}{X_{i j}} \text { Jika } \mathrm{j} \text { adalah atribut biaya } \\
(\text { cost })
\end{array}\right.
$$

Dimanar $_{\mathrm{ij}}$ adalah rating kinerja ternormalisasi(1), Max $\mathrm{X}_{\mathrm{ij}}$ adalah nilai maksimum dari setiap baris (1), kolom Min $\mathrm{X}_{\mathrm{ij}}$ adalah nilai minimum dari setiap baris (1)dan kolom $\mathrm{X}_{\mathrm{ij}}$ adalah baris dan kolom dari matriks(1).

Dengan $r_{i j}$ adalah rating kinerja ternormalisasi dari alternatif $A_{i}$ pada atribut $C_{j} ; i=1,2, \ldots m$ dan $j=1,2, \ldots, n$.

Nilai preferensi untuk setiap alternatif (Vi) diberikan sebagai: 


$$
V_{i}=\sum_{j=1}^{n} W_{j} r_{i j}
$$

Dimana $V_{\mathrm{i}}$ adalah Nilai akhir dari alternative (2), $\mathrm{W}_{\mathrm{j}}$ adalah Bobot yang telah ditentukan (2) dan $r_{i j}$ adalah Normalisa simatriks (2).

Nilai $V_{i}$ yang lebih besar mengindikasikan bahwa alternatif $\mathrm{A}_{\mathrm{i}}$ merupakan alternatif terbaik.

\section{Metode Profile Matching}

Metode profile matching atau pencocokan profil adalah metode yang seringsebagai mekanisme dalam pengambilan keputusan dengan mengasumsikan bahwa terdapat tingkat variabel prediktor yang ideal yang harus dipenuhi olehsubyek yang diteliti, bukannya tingkat minimal yang harus dipenuhi atau dilewati [3].

Dalam proses profile matching secara garis besar merupakan proses membandingkan antara nilai data aktual dari suatu profile yang akan dinilaidengan nilai profil yang diharapkan, sehingga dapat diketahui perbedaan kompetensinya (disebut juga gap), semakin kecil gap yang dihasilkan maka bobot nilainya semakin besar yang berarti memiliki peluang lebih besar untuk direkomendasikan untuk terpilih dalam hal ini sebagai mahasiswa berprestasi.

Berikut adalah beberapa tahapan dan perumusan perhitungan dengan metode profile matching[3] :

1) Pembobotan. Pada tahap ini, akan ditentukan bobot nilai masing-masing aspek dengan menggunakan bobot nilai yang telah ditentukan bagi masing-masing aspekitu sendiri;

2) Pengelompokan Core dan Secondary Factor Setelah menentukan bobot nilai gap kriteria yang dibutuhkan, tiap kriteria dikelompokkan menjadi dua kelompok yaitu core factor dan secondary factor. Core Factor (Faktor Utama) merupakan aspek (kompetensi) yang menonjol/paling dibutuhkan. Untuk menghitung core factor digunakan rumus (3):

$$
N C F=\frac{\sum N C}{\sum I C}
$$

Keterangan :

$\mathrm{NCF}=$ Nilai rata- rata core factor

$\mathrm{NC}=$ Jumlah total nilai core factor

$\mathrm{IC}=$ Jumlah item core factor

Secondary Factor (Faktor Pendukung)adalah item - item selainaspek yang ada pada core factor. Untuk menghitung secondary factor digunakan rumus (4) :

$$
N S F=\frac{\sum N S}{\sum I S}
$$

Keterangan :

NFS = Nilai rata- rata Secondary factor

$\mathrm{NS}=$ Jumlah total nilai Secondary factor

IS= Jumlah item Secondary factor

3) Perhitungan Nilai Total.Dari perhitungan core factor dan secondary factor dari tiap- tiap aspek, kemudian dihitung nilaitotal dari tiap - tiap aspek yang diperkirakan berpengaruh pada kinerja tiap-tiap profile. Untuk menghitung nilai total dari masing-masing aspek, digunakan rumus (5) :

$$
\mathrm{N}=(\mathrm{X}) \% \mathrm{NCF}+(\mathrm{X}) \% \mathrm{NSF}
$$

Keterangan :

$\mathrm{N}=$ Nilai total tiap aspek

$\mathrm{NCF}=$ Nilai rata-rata core factor

NSF = Nilai rata-rata secondary factor

$(\mathrm{X}) \%=$ Nilai persentase yang diinputkan.

\section{Komparasi}

Penelitian komparasi adalah sejenis penelitian deskriptif yang ingin mencari jawaban secara mendasar tentang sebabakibat, dengan menganalisis faktor-faktor penyebab terjadinya ataupun munculnya suatu fenomena tertentu[10].

Studi komparasi adalah suatu bentuk penelitian yang membandingkan antara variable-variabel yang saling berhubungan dengan mengemukakan perbedaan-perbedaan ataupun persamaan-persamaan dalam sebuah kebijakan dan lain-lain.

Penelitian komparatif bersifat ex psot facto, artinya data dikumpulkan setelah semua kejadian yang dipersoalkan berlangsung (lewat). Peneliti mengambil satu atau lebih akibat (sebagai dependent variables) dan menguji data itu dengan menelusuri kembali ke masa lampau untuk mencari sebabsebab, saling hubungan dan maknanya.

Langkah-langkah pokok Penelitian Komparasi:

1) Definisikan masalah.

2) Lakukan penelaahan kepustakaan.

3) Rumuskan hipotesis-hipotesis.

4) Rumuskan asumsi-asumsi yang mendasari hipotesishipotesis itu serta prosedur-prosedur yang akan digunakan.

5) Rancang cara pendekatannya:

- Pilihlah subjek-subjek yang akan digunakan serta sumber-sumber yang relevan.

- Pilihlah atau susunlah teknik yang akan digunakan untuk mengumpulkan data.

- Tentukan kategiri-kategori untuk mengklasifikasikan data yang jelas, sesuai dengan tujuan studi, dan dapat menunjukkan kesamaan atau saling hubungan.

6) Validasikan teknik untuk mengumpulkan data itu, dan interpretasikan hasilnya dalam cara yang jelas dan cermat.

7) Kumpulkan dan analisis data.

8) Susun laporannya.[11]

\section{PEMBAHASAN}

\section{A. Analisis Data}

Pada analisis data dalam penggunaan metode SAW dan metode profile matching dilakukan klasifikasi pembobotan disetiap kriterianya. Dimana dalam pemilihan mitra jasa pengiriman barang ini, diperoleh kriteria-kriteria dan pembobotannya. Kriteria yang digunakan sebagai penilaian adalah sebagai berikut: 
TABELI

PEMbobotan KRITERIA JeNiS ARMADA (C1)

\begin{tabular}{|l|l|c|}
\hline No. & Jenis Armada & Bobot \\
\hline 1 & Darat & 1 \\
\hline 2 & Darat Laut & 2 \\
\hline 3 & Darat Udara & 3 \\
\hline 4 & Udara Laut & 4 \\
\hline 5 & Darat Udara Laut & 5 \\
\hline
\end{tabular}

TABELII

PEMbobotanKRITERIA CAKUPAN (C2)

\begin{tabular}{|l|l|c|}
\hline No. & Cakupan & Bobot \\
\hline 1 & Domestik & 1 \\
\hline 2 & $\begin{array}{l}\text { Domestik \& } \\
\text { International }\end{array}$ & 2 \\
\hline
\end{tabular}

TABLE III

KRITERIAPENGALAMAN PERUSAHAAN (C3)

\begin{tabular}{|l|l|c|}
\hline No. & Pengalaman & Bobot \\
\hline 1 & $<5$ tahun & 1 \\
\hline 2 & $5-10$ tahun & 2 \\
\hline 3 & $10-15$ tahun & 3 \\
\hline 4 & $15-20$ tahun & 4 \\
\hline 5 & $>20$ tahun & 5 \\
\hline
\end{tabular}

TABELIV

TABELPEMBOBOTANKRITERIAHARGA(C4)

\begin{tabular}{|l|l|c|}
\hline No. & Jenis Armada & Bobot \\
\hline 1 & Mahal & 1 \\
\hline 2 & Sedang & 2 \\
\hline 3 & Murah & 3 \\
\hline
\end{tabular}

TABELV

PEMBOBOTANKRITERIAWAKTUPENGIRIMAN (C5)

\begin{tabular}{|l|l|c|}
\hline No. & \multicolumn{1}{|c|}{ Waktu } & Bobot \\
\hline 1 & Lambat & 1 \\
\hline 2 & Agak Lambat & 2 \\
\hline 3 & Agak Cepat & 3 \\
\hline 4 & Cepat & 4 \\
\hline
\end{tabular}

TABELV

PEMBOBotanKRITERIA HASIL PACKING (C6)

\begin{tabular}{|l|l|c|}
\hline No. & Jenis Armada & Bobot \\
\hline 1 & Sangat Baik & 4 \\
\hline 2 & Baik & 3 \\
\hline 3 & Cukup & 2 \\
\hline 4 & Buruk & 1 \\
\hline
\end{tabular}

Sample Altrnatif yang digunakan dalam penelitian ini adalah empat perusahaan yang bergerak di bidang jasa pengiriman barang atau cargo yaitu:

$\mathrm{A} 1=$ PT Cakra Buana $(\mathrm{CB})$

A2 = PT Indah Logistik (IL)

A3 = PT Dinamika Lintas Buana (DLB)

A4 = PT Anugrah Utama Cargo (AUC)

\section{B. Implementasi Metode Simple Additive Weighting}

Langkah pertama yang dilakukan adalah Menentukan alternatif, kriteria dan pembobotan kriteria yang digunakan sebagai acuan dapat dilihat pada analisis data diatas. Dimana terdapat empat alternatif yaitu A1, A2, A3 dan A4. Dan 6 kriteria yaitu yang digunakan dalam penilaian mitra jasa transportasi:

$\mathrm{C} 1$ = Jenis Armada

C2 = Jangkauan

C3 = Pengalaman perusahaan

$\mathrm{C} 4$ = Harga

$\mathrm{C} 5$ = Waktu pengiriman

C6 = Hasil Pacaging

Dan penilaian dengan memberikan pembobotan pada tiap kriteria sebagai berikut:

$$
\begin{aligned}
& \mathrm{C} 1=15 \% \\
& \mathrm{C} 2=15 \% \\
& \mathrm{C} 3=10 \% \\
& \mathrm{C} 4=10 \% \\
& \mathrm{C} 5=20 \% \\
& \mathrm{C} 6=30 \%
\end{aligned}
$$

Setelah bobot dari kriteria disiapkan, langkah kedua adalah memberikan rating kecocokan untuk setiap alternatif pada setiap kriteria dalam pemilihan mitra jasa pengiriman barang yang telah ditentukan sebagai berikut:

\section{TABELVI}

RATING KECOCOKAN DARI SETIAP ALTERNATIF PADA SETIAP KRITERIA

\begin{tabular}{|c|c|c|c|c|c|c|}
\hline \multirow{2}{*}{$\begin{array}{c}\text { Alter } \\
\text { natif }\end{array}$} & \multicolumn{7}{|c|}{ Kriteria } \\
\cline { 2 - 7 } & C1 & C2 & C3 & C4 & C5 & C6 \\
\hline A1 & 5 & 2 & 4 & 2 & 4 & 3 \\
\hline A2 & 4 & 1 & 3 & 2 & 2 & 4 \\
\hline A3 & 3 & 2 & 5 & 3 & 3 & 2 \\
\hline A4 & 5 & 1 & 4 & 1 & 4 & 1 \\
\hline
\end{tabular}

Langkah ketiga adalah pembentukan matrik matriks keputusan, sebagai berikut:

$$
\begin{aligned}
X & =\left[\begin{array}{lllll}
5 & 2 & 42 & 4 & 3 \\
4 & 1 & 32 & 2 & 4 \\
3 & 2 & 53 & 3 & 2 \\
5 & 1 & 41 & 4 & 1
\end{array}\right] \text { Identik dengan } \\
X & =\left[\begin{array}{llll}
r_{11} r_{12} & r_{13} & r_{14} & r_{15} r_{16} \\
r_{21} r_{22} & r_{23} & r_{24} & r_{25} r_{26} \\
r_{31} r_{32} & r_{33} & r_{34} & r_{35} r_{36} \\
r_{41} r_{42} & r_{43} & r_{44} & r_{45} r_{46}
\end{array}\right]
\end{aligned}
$$

Langkah selanjutnya adalah mengihtung nilai normalisasi setiap kriteria dengan Rumus (1). Karena semua alternatif j merupakan atribut keuntungan (benefit) maka proses normalisasinya adalah:

$r_{11}=\frac{5}{\max (5 ; 4 ; 3 ; 5)}=\frac{5}{5}=1$
$r_{12}=\frac{2}{\max (2 ; 1 ; 2 ; 1)}=\frac{2}{2}=1$
$r_{13}=\frac{4}{\max (4 ; 3 ; 5 ; 4)}=\frac{4}{5}=0,80$ 


$$
\begin{aligned}
& r_{14}=\frac{2}{\max (2 ; 2 ; 3 ; 1)}=\frac{2}{3}=0,67 \\
& r_{15}=\frac{4}{\max (4 ; 2 ; 3 ; 4)}=\frac{4}{4}=1 \\
& r_{16}=\frac{3}{\max (3 ; 4 ; 2 ; 1)}=\frac{3}{4}=0,75 \\
& r_{21}=\frac{4}{\max (5 ; 4 ; 3 ; 5)}=\frac{4}{5}=0,80 \\
& r_{22}=\frac{1}{\max (2 ; 1 ; 2 ; 1)}=\frac{1}{2}=0,50 \\
& r_{23}=\frac{3}{\max (4 ; 3 ; 5 ; 4)}=\frac{3}{5}=0,60 \\
& r_{24}=\frac{2}{\max (2 ; 2 ; 3 ; 1)}=\frac{2}{3}=0,67 \\
& r_{25}=\frac{2}{\max (4 ; 2 ; 3 ; 4)}=\frac{2}{4}=0,50 \\
& r_{26}=\frac{4}{\max (3 ; 4 ; 2 ; 1)}=\frac{4}{4}=1 \\
& r_{46}=\frac{1}{\max (3 ; 4 ; 2 ; 1)}=\frac{1}{4}=0,25 \\
& r_{45}=\frac{3}{\max (4 ; 2 ; 3 ; 4)}=\frac{1}{\max (4 ; 3 ; 5 ; 4)}=\frac{4}{5}=0,80 \\
& r_{31}=\frac{3}{\max (5 ; 4 ; 3 ; 5)}=\frac{3}{5}=0,60 \\
& r_{32}=\frac{2}{\max (2 ; 1 ; 2 ; 1)}=\frac{2}{2}=1 \\
& r_{33}=\frac{3}{\max (4 ; 3 ; 5 ; 4)}=\frac{2}{5}=0,60 \\
& r_{34}=\frac{2}{\max (2 ; 2 ; 3 ; 1)}=\frac{3}{3}=0,67 \\
& r_{15}=\frac{3}{\max (4 ; 2 ; 3 ; 4)}=\frac{3}{4}=0,75 \\
& r_{36}=\frac{2}{4}=0,50 \\
& \left.r_{42}=\frac{1}{5}=1 ; 4 ; 2 ; 1\right)
\end{aligned}
$$

Kemudian hasil normalisasi dituangkan dalam matriks normalisasi sebagai berikut:

$$
r=\left[\begin{array}{lllll}
1,00 & 1,00 & 0,800,67 & 1,00 & 0,75 \\
0,80 & 0,50 & 0,600,67 & 0,50 & 1,00 \\
0,60 & 1,00 & 0,600,67 & 0,75 & 0,50 \\
1,00 & 0,50 & 0,800,30 & 1,00 & 0,50
\end{array}\right]
$$

Setelah matriks normalisasi terbentuk, kemudian menentukan bobot yang akan digunakan untuk perengkingan, yaitu:

$W=\left[\begin{array}{lllll}0,15 & 0,15 & 0,100,10 & 0,20 & 0,30\end{array}\right]$
Langkah keenam pencarian perankingan atau nilai terbaik dengan memasukan setiap criteria yang diberikan dengan menggunakan rumus (2). Maka perhitungan perengkingannya adalah:

$V_{1}=(0,15)(1)+(0,15)(1)+(0,10)(0,80)+(0,10)(0,67)+(0,20)(1)+$ $(0,30)(0,75)=\mathbf{0 , 6 5}$

$$
\begin{aligned}
& V_{2}=(0,15)(0,80)+(0,15)(0,50)+(0,10)(0,60)+(0,10)(0,67)+ \\
& (0,20)(0,67)+(0,3)(0,75)=\mathbf{0 , 4 2} \\
& V_{3}=(0,15)(0,60)+(0,15)(1)+(0,10)(0,60)+(0,10)(0,67)+ \\
& (0,20)(0,75)+(0,3)(0,50)=\mathbf{0 , 5 2} \\
& V_{4}=(0,15)(1)+(0,15)(0,50)+(0,10)(0,80)+(0,10)(0,30)+ \\
& (0,20)(1)+(0,30)(0,25)=\mathbf{0 , 5 4}
\end{aligned}
$$

Maka hasil perengkingan dapat dilihat pada tabel berikut:

\section{TABELVII}

HASILPERENGKINGAN

\begin{tabular}{|l|c|c|}
\hline No. & Alternatif & Rangking \\
\hline 1 & A1 & $\mathbf{0 , 6 5}$ \\
\hline 2 & A4 & 0,54 \\
\hline 3 & A3 & 0,52 \\
\hline 4 & A2 & 0,42 \\
\hline
\end{tabular}

Diantara V1, V2, V3 dan V4 yang mendapatkan nilai terbesaradalah V1, sehinggamitra jasa pengiriman barang (alternatif) yang terpilih yaitu V1= PT. Cakra Buana (CB).

\section{Implementasi Metode Profile Matching}

Langkah pertama yang dilakukan adalah melakukan analisa bobot gap. Dimana untuk bobot nilai dari tiap sub kriteria telah ditentukan pada tahap analisa data diatas (tabel I s/d tabel VI).

Langkah kedua yaitu penentuan nilai profil pencapaian akan ditentukan oleh pihak manajemen dengan range nilai antara 1 sampai 5. Dari nilai-nilaitersebut akan dilakukan proses perhitungan gap antara nilai profil mitra dengan nilai profil pencapaian. Adapun profil pencapaian yang telah ditentukan oleh manajemen dapat dilihat pada tabel VIII:

TABELVIII

NILAI PRofil PENCAPAIAN

\begin{tabular}{|c|c|c|}
\hline Kriteria & $\begin{array}{c}\text { Profil } \\
\text { Pencapaian }\end{array}$ & Jenis \\
\hline C1 & 5 & Core factor \\
\hline C2 & 2 & Core factor \\
\hline C3 & 3 & Secondary factor \\
\hline C4 & 2 & Secondary factor \\
\hline C5 & 4 & Core factor \\
\hline C6 & 3 & Core factor \\
\hline
\end{tabular}


Setelah menentukan nilai profil pencapaian, maka dapat dilakukan perhitungan Gap dengan rumus:

\section{GAP = Profil Mitra - Profil Pencapaian}

Maka hasil perhitungan gap dapat dilihat pada tabel IX sebagai berikut:

TABEL IX

GAP KOMPETENSI

\begin{tabular}{|c|c|c|c|c|c|c|c|}
\hline \multirow{2}{*}{ Alternatif } & \multicolumn{6}{|c|}{ Kriteria } & \\
\hline & C1 & $\mathrm{C2}$ & C3 & C4 & C5 & C6 & \\
\hline A1 & 5 & 2 & 4 & 2 & 4 & 3 & \multirow{4}{*}{ בד } \\
\hline A2 & 4 & 1 & 3 & 2 & 2 & 4 & \\
\hline A3 & 3 & 2 & 5 & 3 & 3 & 2 & \\
\hline A4 & 5 & 1 & 4 & 1 & 4 & 1 & \\
\hline $\begin{array}{c}\text { Nilai } \\
\text { Pencapaian }\end{array}$ & 5 & 2 & 3 & 2 & 4 & 3 & \\
\hline A1 & 0 & 0 & 1 & 0 & 0 & 0 & \multirow{4}{*}{ ڤ్ } \\
\hline $\mathrm{A} 2$ & -1 & -1 & 0 & 0 & -2 & 1 & \\
\hline A3 & -2 & 0 & 2 & 1 & -1 & -1 & \\
\hline A4 & 0 & -1 & 1 & -1 & 0 & -2 & \\
\hline
\end{tabular}

Setelah diperoleh gap dari masing-masing alternatif, setiap profil calon mitra di beri bobot nilai dengan patokan table bobot nilai gap. Pembobotan yang digunakan pada penelitian ini dapatdilihat pada tabel $\mathrm{X}$ dibawah ini:

TABEL $X$

BOBOT NILAI GAP

\begin{tabular}{|c|c|l|}
\hline $\begin{array}{c}\text { Selisih } \\
\text { Gap }\end{array}$ & $\begin{array}{c}\text { Bobot } \\
\text { Nilai }\end{array}$ & \multicolumn{1}{|c|}{ Keterangan } \\
\hline 0 & 5 & Kompetensi sesuai dengan yang dibutuhkan \\
\hline 1 & 4,5 & Kompetensi kelebihan 1 tingkat/level \\
\hline-1 & 4 & Kompetensi kurang 1 tingkat/level \\
\hline 2 & 3,5 & Kompetensi kelebihan 2 tingkat/level \\
\hline-2 & 3 & Kompetensi kurang 2 tingkat/level \\
\hline 3 & 2,5 & Kompetensi kelebihan 3 tingkat/level \\
\hline-3 & 2 & Kompetensi kurang 3 tingkat/level \\
\hline 4 & 1,5 & Kompetensi kelebihan 4 tingkat/level \\
\hline-4 & 1 & Kompetensi kurang 4 tingkat/level \\
\hline
\end{tabular}

Dengan demikian bobot nilai gap dari tiap alternatif dapat dilihat pada tabel XI berikut:

TABELXI

PEMBOBOTAN NILAI GAP

\begin{tabular}{|c|c|c|c|c|c|c|}
\hline \multirow{2}{*}{ Alternatif } & \multicolumn{7}{|c|}{ Kriteria } \\
\cline { 2 - 7 } & C1 & C2 & C3 & C4 & C5 & C6 \\
\hline A1 & 5 & 5 & 4,5 & 5 & 5 & 5 \\
\hline A2 & 4 & 4 & 5 & 5 & 3 & 4,5 \\
\hline A3 & 3 & 4 & 3,5 & 4,5 & 4 & 4 \\
\hline A4 & 5 & 4 & 4,5 & 4 & 5 & 3 \\
\hline
\end{tabular}

Langkah ketiga adalah melakukan perhitungan berdasarkan pengelompkan core factor dan secondary factor. Berdasarkan tabel VIII, yang merupakan core factor adalah kriteria C1,C2,
C5 dan C6. Sedangkan kriteria secondary factor adalah C3 dan $\mathrm{C} 4$.

Berdasarkan tabel XI maka dilakukan perhitungan dengan rumus (3) dan (4) untuk diperoleh nilai rata-rata Core Factor(NCF) dan rata-rata Secondary Factor (NSF). Hasilnya dapat dilihat pada table XII berikut:

TABEL XII

Nilai RATA-RATA CORE FACTOR DAN SECONDARY FACTOR

\begin{tabular}{|c|c|c|}
\hline Kriteria & $\begin{array}{c}\mathbf{N C F} \\
(\mathbf{C} 1+\mathbf{C} \mathbf{2}+\mathbf{C 5}+\mathbf{C 6}) / \mathbf{4}\end{array}$ & $\begin{array}{c}\mathbf{N S F} \\
(\mathbf{C 3 + C 4}) / \mathbf{2}\end{array}$ \\
\hline A1 & 5 & 4,75 \\
\hline A2 & 3,875 & 5 \\
\hline A3 & 4 & 4 \\
\hline A4 & 4,25 & 4,25 \\
\hline
\end{tabular}

Setelah diperoleh nilai NCF dan NSF, langkah selanjutnya nilai total berdasarkan persentase dari core dan secondary yangdiperkirakan berpengaruh terhadap kinerja tiap-tiap profil. Adapun presentase yang diinputkan adalah untuk core factor $80 \%$ dan secondary factor $20 \%$. Sihingga nilai total yang diperoleh berdasarkan rumus (5) adalah sebagai berikut (tabel XIII):

TABELXIII

PERHITUNGAN NilAi TOTAL

\begin{tabular}{|c|c|c|c|}
\hline Alternatif & NCF & NSF & $\begin{array}{c}\text { Nilai Total } \\
(\mathbf{8 0 \%} * \mathbf{N C F})+(\mathbf{2 0 \%} * \mathbf{N S F})\end{array}$ \\
\hline A1 & 5 & 4,75 & 4,95 \\
\hline A2 & 3,875 & 5 & 4,1 \\
\hline A3 & 4 & 4 & 4 \\
\hline A4 & 4,25 & 4,25 & 4,25 \\
\hline
\end{tabular}

Langkah terakhir setelah diperoleh nilai totol, maka dilakukan proses perangkingan dengan mengurutkan dari nilai paling besar sampai dengan terkecil. Dimana nilai terbesar merupakan alternatif terpilih.

TABELXIV

PERENGKINGAN ALTERNATIF

\begin{tabular}{|c|c|c|}
\hline Alternatif & Total Nilai & Peringkat \\
\hline A1 & 4,95 & 1 \\
\hline A4 & 4,25 & 2 \\
\hline A2 & 4,1 & 3 \\
\hline A3 & 4 & 4 \\
\hline
\end{tabular}

Dari hasil perengkingan pada tabel XIV, hasilnya adalah A1 = PT Cakra Buana merupakan alternatif terpilih berdasarkan metode Profile Matching sebagai mitra jasa pengiriman barang. 
D. Hasil Komparasi Metode Simple Additive Weighting dan Profil Matching

Berdasarkan implementasi metode SAW dan Profile Matching maka diperoleh hasil komparasi perengkingan dari kedua metode tersebut pada tabel XV berikut:

TABEL XIV

HASIL KOMPARASI METODE SAW DAN PM

\begin{tabular}{|c|c|c|c|c|}
\hline \multirow{2}{*}{$\begin{array}{c}\text { Pering } \\
\text { kat }\end{array}$} & \multicolumn{2}{|c|}{ Metode SAW } & \multicolumn{2}{c|}{ Metode PM } \\
\cline { 2 - 5 } & Alternatif & $\begin{array}{c}\text { Nilai } \\
\text { Akhir }\end{array}$ & Alternatif & $\begin{array}{c}\text { Nilai } \\
\text { Akhir }\end{array}$ \\
\hline 1 & A1 & $\mathbf{0 , 6 5}$ & A1 & $\mathbf{4 , 9 5}$ \\
\hline 2 & A4 & 0,54 & A4 & 4,25 \\
\hline 3 & A3 & 0,52 & A2 & 4 \\
\hline 4 & A2 & 0,42 & A3 & 4,1 \\
\hline
\end{tabular}

Terdapat perbedaan pada perengkingan alternatif ke -3 dan ke -4 yaitu untuk metode SAW peringkat ketiga A3 dan peringkat ke empat A2. Sedangkan pada metode PM kebalikannya. Akan tetapi tujuan dari penelitan ini adalah mencari alternatif terbaik, dan hasil komparasi diatas menghasilkan alternatif yang sama yaitu A1= PT Cakra Buana. Sehingga penilaian dengan metode SAW muapun Profile Matching dapat diterapkan oleh pihak manajemen dalam menentukan mitra jasa pengirmian barang.

\section{KESIMPULAN}

Kedua metode yang telah dilakukan perhitungan dapat menunjukan hasil akhir yang sama dan diperoleh berdasarkan kriteria dan data yang sama pula. Dalam metode Simple Additive Weighting alternatif terpilih adalah PT Cakra Buana. Hasil tersebut juga merupakan hasil akhir pada metode Profile Matching.

Metode Simple Additive Weighting dan Profile Matching merupakan metode yang hasil akhirnya berupa perengkingan dari proses perhitungan yang telah dilakukan. Jadi, kedua metode ini dapat diterapkan dan diimplementasikan dalam pemilihan mitra jasa pengiriman barang untuk membantu pengambilan keputusan pihak manajemen, karena kedua metode ini menghasilkan alternatif terbaik yang sama.

\section{REFERENSI}

[1] Akhirina, Tri Yani, Sistem Pendukung Keputusan Pemilihan Mitra Jasa Pengiriman Barang Menggunakan Metode Simple Additive Weighting $(S A W)$. Jurnal Jupiter - Universitas Borobodur : Jakarta, 2016, Vol 2 No. 1.

[2] Sari, Bety Wulan,. Perbandingan Metode Profile Matching dan Simple Additive Weighting pada Penentuan Jurusan Siswa Kelas X SMA N 2 Ngaglik. Jurnal DASI - STMIK AMIKOM: Yogyakarta, 2015, Vol 16 No. 1

[3] Kusrini, Konsep dan Aplikasi Sistem Pendukung Keputusan, Yogyakarta : Penerbit Andi, 2007.

[4] Alter, Steven., Information System Foundation of e-business, London Prantice Hall, 2002

[5] Mc Leod Jr, Raymond.., Sistem Informasi Manajemen,edisi V III, Jakarta : Prenhallindo, 1998.

[6] Surbakti, Irfan., Sistem Pendukung Keputusan, Yogyakarta : Graha Ilmu, 2002.

[7] E. Turban, Jay E. Aronson, Ting Peng Liang., Decision Support Systeman and Itelegant System, 7th ed, New Jersey : Pearson Education, 2005.

[8] Fishburn, P.C., A Problem-Based Selection of Multi Atribute Decision Making Method. London : Blockwell Publishing, 1967.

[9] Mac Crimmon, K.R., Decision Making Among Mulitiple Atribute Alternatives: A Source and Consolidated Approach. RAND Memorandum RM 4823 ARPA, 1968

[10] M. Nazir. Metodologi penelitian. Bogor :Ghalia Indonesia. 2005

[11] Sumadi Suryabrata, Metodologi Penelitian, Jakarta:RajawaliPers, 2011. 